\title{
Główne obowiązki przedsiębiorcy na gruncie Ustawy z dnia 16 września 2011 r. o timeshare
}

\section{Main Obligations of an Entrepreneur in the Context of the Timeshare Act of 16 September 2011}

\begin{abstract}
Streszczenie: Przedmiot rozważań zawartych w niniejszym artykule stanowią regulacje zamieszczone w Ustawie z dnia 16 września 2011 r. o timeshare (Dz.U. z 2011 r. nr 230, poz. 1370). Celem wywodu jest zidentyfikowanie - metodą analizy prawnej obowiązujących przepisów - zasadniczych komponentów normatywnych wyznaczających główne obowiązki przedsiębiorcy, a tym samym jego pozycję prawną na gruncie rozpatrywanej ustawy. Oprócz tego szczegółowego celu ogólnym celem artykułu jest przekazanie szerszemu kręgowi czytelników podstawowej wiedzy o timeshare. Wynika to $\mathrm{z}$ faktu, że timeshare nie jest tematyką często poruszaną w literaturze naukowej oraz w ramach szeroko pojętego rynku dydaktycznego. Dodatkowo, prezentowany artykuł zawiera analizę problemu badawczego dotyczącego pozycji prawnej przedsiębiorcy w relacjach $\mathrm{z}$ konsumentem. W artykule scharakteryzowano umowy regulowane ustawą o timeshare, zakres przedmiotowy tej ustawy oraz pojęcia przedsiębiorcy i konsumenta. Opisano również obowiązki przedsiębiorcy związane z utrzymaniem obiektu timeshare oraz przesłanki pozwalające odstąpić konsumentowi od umowy. W dalszej kolejności przedstawiono szczegółowe powinności i obostrzenia nałożone na przedsiębiorców, jak również ocenę poszczególnych rozwiązań prawnych dotyczących relacji pomiędzy przedsiębiorcą a konsumentem. Przeprowadzona analiza pozwoliła stwierdzić, że pozycja prawna przedsiębiorcy została bardzo precyzyjnie uregulowana, co sprzyja wiarygodności obrotu prawnego. Ponadto, ustawodawca słusznie postanowił szczegółowo uregulować warunki wypowiedzenia umowy timeshare (zob. art. 40 ust. 2 i 3 oraz art. 41 ustawy o timeshare, choć należy pamiętać również o art. 365 Ustawy z dnia 23 kwietnia 1964 Kodeks cywilny (tekst jednolity: Dz.U. z 2019 r., poz. 1145)), oraz zagadnienie odstąpienia od umowy w rozdziale 5 omawianej ustawy o timeshare, bowiem te instytucje prawne są często ze sobą mylone.
\end{abstract}

Abstract: Regulations included in the Timeshare Act of September 16, 2011 (Journal of Laws of 2011, no. 230, item 1370) are the matter of considerations included in this article. The aim of the reasoning is to indentify - by method of legal analysis of provisions in force - the fundamental normative components stating the main obligations of an entrepreneur, and thus his legal position in terms of the examined act. Apart from this detailed aim, the general aim of the article is to convey to a wider audience the basic knowledge about the timeshare. It results from the fact, that the timeshare is not a subject matter often 
discussed in research literature and within the widely understood educational market. Additionally, presented article contains an analysis of a research problem referring to legal position of an entrepreneur in relations with a consumer. The article characterises contracts regulated by the Timeshare Act, subject range of this act and concepts of an entrepreneur and a consumer. It also describes obligations of an entrepreneur connected with maintenance of the object of timeshare and conditions allowing the consumer to withdraw from a contract. Subsequently, it presents detailed duties and restrictions imposed on entrepreneurs, as well as opinion on particular legal solutions referring to relations between an entrepreneur and a consumer. Realised analysis allowed to ascertain that the legal position of an entrepreneur has been very precisely regulated, which promotes trustworthiness of legal transactions. Moreover, the legislator rightly decided to regulate in detail the conditions of noticing timeshare contract - see article 40 item 2 and 3 as well as article 41 of the Timeshare Act, though one should remember also about article $365^{1}$ of the Civil Code of April 23, 1964 (consolidated text: Journal of Laws 2019 item 1145) - and the issue of contract renouncement in chapter 5 of discussed Timeshare Act, because these legal institutions are often mistaken one for another.

Słowa kluczowe: konsument; przedsiębiorca; timeshare; zakwaterowanie

Keywords: consumer; entrepreneur; quarters; timeshare

Otrzymano: 27 maja 2019

Received: 27 May 2019

Zaakceptowano: 12 sierpnia 2019

Accepted: 12 August 2019

\section{Sugerowana cytacja/Suggested citation:}

Woroniecki, P.M. (2019). Główne obowiązki przedsiębiorcy na gruncie Ustawy z dnia 16 września 2011 r. o timeshare. Przedsiębiorczość - Edukacja [Entrepreneurship - Education], 15(2), 214-226. doi: $10.24917 / 20833296.152 .15$

\section{Wstęp}

Kilka lat, które upłynęły od momentu uchwalenia Ustawy z dnia 16 września 2011 r. o timeshare (Dz.U. z 2011 r. nr 230, poz. 1370), nie przyniosło - poza nielicznymi wyjątkami - gruntownej analizy doktrynalnej rozwiązań w niej zawartych. Z punktu widzenia przedsiębiorców nie jest to sytuacja komfortowa, bowiem ten akt prawny, pomimo swojej niewielkiej objętości, zawiera rozwiązania prawne, których nieznajomość może mieć dla nich poważne konsekwencje. Należy w tym miejscu wyjaśnić, że w przedmiotowych ramach ustawy mieszczą się zasady i procedura zawierania między podmiotem gospodarczym a konsumentem czterech rodzajów umów: umowy o timeshare, umowy o długoterminowy produkt wakacyjny, umowy dotyczącej pośredniczenia w odsprzedaży timeshare bądź długoterminowego produktu wakacyjnego oraz umowy związanej z uczestnictwem w systemie wymiany (art. 1 ust. 1 ustawy o timeshare). Ramy te determinują jednocześnie obszar rozważań zawartych w niniejszym opracowaniu,

Niezależnie od wspomnianego wyżej braku szerszego zainteresowania ze strony nauki, również rynek edukacyjny i szkoleniowy nie zajmuje się szerzej problematyką timeshare, co w dłuższej perspektywie może hamować rozwój tego segmentu działalności gospodarczej. Ogólnym celem niniejszego opracowania jest próba wypełnienia tej swoistej luki naukowo-dydaktycznej przez zainteresowanie szerszego grona odbiorów zagadnieniem timeshare. W zakresie źródeł normatywnych w artykule oparto się przede wszystkim na przepisach zawartych we wspomnianej wyżej ustawie o timeshare, które przez 
zastosowanie wobec nich metody analizy prawnej pozwalają zrekonstruować główne obowiązki przedsiębiorcy wyznaczające jego pozycję prawną w ramach tej ustawy. Jest to cel szczegółowy opracowania. Dodatkowo, opracowanie zawiera odniesienia do reprezentatywnych poglądów doktryny.

Obok wyżej sformułowanych celów zamysłem prezentowanego tekstu jest również rozstrzygnięcie istotnego problemu badawczego dotyczącego pozycji prawnej przedsiębiorcy $\mathrm{w}$ relacjach $\mathrm{z}$ konsumentem, który to problem można sprowadzić do trzech szczegółowych pytań badawczych. Po pierwsze, czy wprowadzone przez ustawodawcę regulacje prawne są adekwatne do założonych przez niego celów związanych $\mathrm{z}$ ochroną konsumenta (chodzi tutaj zwłaszcza o przepisy dotyczące obowiązków informacyjnych spoczywających na przedsiębiorcy oraz konsumenckiego prawa do odstąpienia od umowy bez podawania przyczyn), po drugie, czy polski prawodawca w sposób odpowiedni wyważył interesy przedsiębiorcy i konsumenta, oraz po trzecie, czy występujący obecnie kierunek ewolucji prawa konsumenckiego został przez polskiego prawodawcę dostrzeżony i odpowiednio zaadoptowany do ustawy o timeshare.

Ogólna charakterystyka umowy timeshare

oraz pozostałych umów regulowanych ustawą

Na wstępie należy zaznaczyć, że zarówno w krajach należących do Unii Europejskiej, jak i w USA umowa timesharingu znalazła zastosowanie już z początkiem lat 70. XX w., z tym że idea timesharingu narodziła się nieco wcześniej, bo w drugiej połowie lat 60 . we Francji (Zaradkiewicz, 1997: 185). Trzeba też podkreślić, że timesharing nie posiada tożsamego kształtu w różnych systemach prawnych (Stecki, 2002: 114). Zwykle umowa timesharingu polega na korzystaniu z rzeczy, choć jej przedmiot mogą stanowić też inne dobra (Fuchs, 2012: 153). Przykładowo, wymieniając w doktrynie potencjalne przedmioty timesharingu, pisze się o hotelach, pensjonatach, domach wypoczynkowych, bungalowach, jachtach, samochodach (Zaradkiewicz, 1997: 186). Zwolennicy rozszerzenia rozumienia przedmiotu timesharingu wskazują na konieczność objęcia nim zarówno wymienionych wyżej jachtów czy samochodów, jak i łodzi (w szczególności motorowych), rowerów wodnych, kajaków, motocykli, skuterów, zwierząt, w tym koni dla osób zainteresowanych sportem hippicznym (Stecki, 2002: 78). Natomiast jako wyłącznego przedmiotu timesharingu nie można traktować usług (Stecki, 2002: 72). Podsumowując zatem, timesharingiem jest,,specyficzna forma korzystania z rzeczy (najczęściej nieruchomości), przy czym uprawnienie określonej osoby w konkretnym przypadku wyznacza się za pomocą kryterium czasu" (Fuchs, 2001: 49). Jako najważniejszą zaletę timesharingu należy traktować jego relatywnie niskie koszty, co można zauważyć przede wszystkim, gdy go porównamy z kosztem nabycia lokalu znajdującego się w miejscowości o walorach wypoczynkowych (Fuchs, 1997: 36).

Pamiętając o tych generalnych uwagach, w dalszej kolejności należy przeanalizować rozwiązania zawarte $\mathrm{w}$ aktualnie obowiązującej w Polsce ustawie o timeshare, rozpoczynając od przytoczenia normatywnej definicji umowy timeshare zawartej w art. 2 ust. 1 wspomnianej wyżej ustawy, który to przepis stanowi, że pod pojęciem umowy timeshare należy rozumieć,,umowę, na podstawie której konsument, odpłatnie, nabywa prawo do korzystania, w okresach wskazanych w umowie, z co najmniej jednego miejsca zakwaterowania, zawartą na okres dłuższy niż rok". Jednocześnie czas, na który zawiera się 
umowę, ustalany jest,,z uwzględnieniem postanowień umowy umożliwiających jej przedłużenie w sposób wyraźny lub dorozumiany, oraz faktycznie dokonanych uzgodnień między stronami co do możliwości dalszego korzystania przez konsumenta z miejsca zakwaterowania" (art. 2 ust. 2 ustawy o timeshare).

Od umowy timeshare należy odróżnić umowę o długoterminowy produkt wakacyjny charakteryzującą się tym, że musi być ona zawarta na okres przekraczający rok, a na jej podstawie konsument - za opłatą - otrzymuje uprawnienie do uzyskiwania rabatów, zniżek bądź innych korzyści odnoszących się do zakwaterowania, jak również - o ile umowa to przewiduje - prawo do nabywania usług dotyczących podróży, a zwłaszcza uprawnienie pozwalające skorzystać z danego miejsca zakwaterowania, czy też prawo do nabywania usług transportowych lub innych jeszcze usług (art. 3 ust. 1 ustawy o timeshare). Kolejną umową wymagającą sprecyzowania jest umowa pośrednictwa w odsprzedaży timeshare lub długoterminowego produktu wakacyjnego, polegająca na tym, że na jej podstawie przedsiębiorca bierze na siebie obowiązek, odpłatnie, realizowania czynności prawnych bądź faktycznych ukierunkowanych na nabycie lub zbycie przez konsumenta uprawnień $z$ umów: timeshare bądź o długoterminowy produkt wakacyjny (art. 4 ustawy o timeshare).

I wreszcie możemy mieć do czynienia z umową o uczestnictwo w systemie wymiany, która to umowa cechuje się tym, iż na jej podstawie przedsiębiorca - za opłatą - daje,,konsumentowi dostęp do sytemu wymiany, w ramach którego konsument uzyskuje prawo do korzystania $\mathrm{z}$ miejsca zakwaterowania lub prawo do nabycia innych usług świadczonych przez przedsiębiorcę, w zamian za umożliwienie innym konsumentom korzystania z miejsca zakwaterowania będącego przedmiotem jego umowy timeshare" (art. 5 ustawy o timeshare).

Zakres regulacji ustawy o timeshare.

Pojęcia przedsiębiorcy i konsumenta

Aby właściwie zidentyfikować status przedsiębiorcy na gruncie ustawy o timeshare, należy wyjść od ogólnego zapisu zawartego w art. 1 ust. 2 wspomnianej ustawy, w myśl którego ustawa ta reguluje także zasady, na jakich konsumenci - podpisujący z przedsiębiorcami umowy wyszczególnione w powołanym już wyżej art. 1 ust. 1 ustawy o timeshare - podlegają ochronie, jak również określa ona uprawnienia i obowiązki zarówno przedsiębiorców, jak i konsumentów zawierających tego rodzaju umowy oraz konsekwencje odstąpienia przez tych ostatnich od rzeczonych umów. Podkreślenie w tym przepisie kwestii ochrony konsumentów nie jest przypadkowe i ma swoje uzasadnienie związane z historią samego timesharingu. Otóż już w literaturze przedmiotu $\mathrm{z}$ lat 90 . i w pierwszej dekadzie XXI w. zwracano uwagę na to zagadnienie. W szczególności podkreślano - pisząc o timesharingu - że dla zapewnienia właściwego działania rynku wewnętrznego w Polsce konieczne jest wprowadzenie takich rozwiązań normatywnych, które dadzą odpowiednią ochronę słusznym interesom konsumentów (Preussner-Zamorska, Traple, 1998: 537). Zwracano też uwagę na stosowanie agresywnych metod sprzedażowych w celu zawarcia umów timesharingowych, reklamy cechującej się natarczywością, a ponadto wskazywano na częstą praktykę nieprzejrzystego redagowania takich umów przy zastosowaniu języka, który dla większej części kontrahentów był niezrozumiały (Gołaczyńki, 2001: 61-62). Trafnie akcentowano również, że zjawisko integracji europejskiej ma kluczowe znaczenie 
dla timesharingu, bowiem daje szansę swobodnych wyjazdów zagranicznych, a to z kolei niejednokrotnie powoduje pochopne podejmowanie decyzji w sprawie zawarcia umowy timesharingu (Grzyb, 2004: 47).

Omawiana ustawa o timeshare nie określa bezpośrednio pojęcia przedsiębiorcy, ale w art. 6 pkt 4 zawiera odwołanie do znaczenia tego pojęcia określonego w Ustawie $z$ dnia 23 kwietnia 1964 r. Kodeks cywilny (tekst jednolity: Dz.U. z 2019 r., poz. 1145). Zgodnie $\mathrm{z}$ art. $43^{1}$ Kodeksu cywilnego przedsiębiorca to „osoba fizyczna, osoba prawna i jednostka organizacyjna, o której mowa w art. $33^{1} \$ 1$, prowadząca we własnym imieniu działalność gospodarczą lub zawodową". W kontekście brzmienia tego przepisu trzeba zaznaczyć, że działalność gospodarczą należy wiązać z pojęciem obrotu gospodarczego nakierowanego na przynoszenie dochodów oraz zysków, a więc jako działalności gospodarczej nie można traktować wytwarzania czegokolwiek tylko na swoje potrzeby, nawet gdyby przynosiło to określone korzyści materialne (Dmowski, aktualizacja Trzaskowski, 2014: 217-218). Należy też podkreślić, że przytoczone wyżej ustawowe określenie przedsiębiorcy ma autonomiczne znaczenie w sferze stosunków prywatnoprawnych (Kruczalak, zaktualizowała i uzupełniła Kruczalak-Jankowska, 2008: 85).

Również pojęcie konsumenta nie jest wyjaśnione w ustawie o timeshare, a tylko podobnie jak w przypadku przedsiębiorcy - zawiera ona w art. 6 pkt 2 odesłanie do znaczenia tego terminu na gruncie Kodeksu cywilnego. I tak, w myśl art. $22^{1}$ tego kodeksu, konsumentem jest osoba fizyczna dokonująca „z przedsiębiorcą czynności prawnej niezwiązanej bezpośrednio z jej działalnością gospodarczą lub zawodową".

Obowiązki przedsiębiorcy w zakresie utrzymania obiektu timeshare. Wypowiedzenie umowy timeshare

Niezwykle doniosłym przepisem wyznaczającym pozycję przedsiębiorcy wobec konsumenta jest art. 7 ustawy o timeshare, zgodnie z którym nieważne są zapisy zawarte $\mathrm{w}$ umowie pośrednictwa $\mathrm{w}$ odsprzedaży timeshare lub długoterminowego produktu wakacyjnego (na gruncie omawianej ustawy umowa ta określana jest mianem umowy pośrednictwa w odsprzedaży), umowie timeshare, umowie o długoterminowy produkt wakacyjny, umowie o uczestnictwo w systemie wymiany i umowach powiązanych, które nie są tak korzystne dla konsumentów, jak postanowienia ustawy, czego konsekwencją jest obowiązek zastosowania zamiast nich przepisów ustawy.

Wspomniany wyżej przepis wyznacza normatywne granice, w ramach których mogą poruszać się kontrahenci, natomiast szczegółowych rozwiązań determinujących status prawny przedsiębiorców należy poszukiwać w dalszych częściach ustawy. I tak, zgodnie $\mathrm{z}$ art. 37 ust. 1 ustawy o timeshare, na przedsiębiorcy, który podpisał umowę timeshare, spoczywa obowiązek utrzymywania miejsca zakwaterowania oraz innych obiektów udostępnianych konsumentowi w oparciu o tę umowę w stanie nadającym się do umówionego użytkowania przez cały okres obowiązywania umowy, a zwłaszcza musi on realizować naprawy i inne nakłady konieczne. $Z$ drugiej strony, o czym z kolei mówi art. 38 ustawy o timeshare, konsument nie musi - o ile w umowie timeshare nie postanowiono inaczej - ponosić nakładów zarówno na miejsce, w którym nastąpiło zakwaterowanie, jak i na inne jeszcze obiekty, które zostały mu udostępnione w oparciu o tę umowę. Co więcej, w art. 39 ustawy o timeshare ustawodawca zadeklarował, że jeżeli w trakcie obowiązywania umowy timeshare wystąpi konieczność napraw miejsca zakwaterowania bądź innych 
obiektów udostępnionych konsumentowi na podstawie tej umowy, bez których są one nieprzydatne do umówionego użytkowania, a którymi w myśl postanowień umownych nie jest obciążony konsument, to w takiej sytuacji może on wskazać przedsiębiorcy właściwy termin do realizacji napraw, przy czym konsekwencją jego bezskutecznego upływu jest prawo konsumenta do dokonania niezbędnych napraw, których koszt ponosi przedsiębiorca. W doktrynie trafnie wskazuje się, że to prawo konsumenta do realizacji napraw, których koszt pokrywa przedsiębiorca, należy rozumieć w ten sposób, że koszty napraw pokrywane są samodzielnie przez konsumenta, a potem dopiero może on skierować do przedsiębiorcy żądanie zwrotu wydatków z tego tytułu (Sagan, 2014: 123).

Inaczej przedstawia się sytuacja, gdy miejsce zakwaterowania bądź inne obiekty oddane konsumentowi w oparciu o umowę timeshare cechują się wadami ograniczającymi ich zdatność do umówionego użytkowania, bowiem w takiej sytuacji konsumentowi przysługuje prawo żądania stosownego zmniejszenia wynagrodzenia za okres trwania wad (art. 40 ust. 1 ustawy o timeshare). W pewnych przypadkach konsument może dokonać wypowiedzenia, i to z natychmiastowym skutkiem, mianowicie wtedy, gdy miejsce zakwaterowania bądź inne obiekty udostępnione konsumentowi na podstawie umowy timeshare cechowały się - w momencie ich przekazania konsumentowi - wadami uniemożliwiającymi ich użytkowanie w sposób przewidziany w umowie, albo jeśli tego rodzaju wady zaistniały później, a strona umowy będąca przedsiębiorcą, pomimo otrzymanego zawiadomienia, zaniechała ich usunięcia we właściwym czasie, albo jeżeli usunięcie wad nie jest możliwe (art. 40 ust. 2 ustawy o timeshare). Zasadą jest, że roszczenie o zmniejszenie wynagrodzenia przez wzgląd na wady, jak i uprawnienie do dokonania wypowiedzenie umowy $\mathrm{z}$ natychmiastowym skutkiem, nie przysługuje podmiotowi będącemu konsumentem, o ile w momencie zawierania umowy miał wiedzę o wadach (art. 40 ust. 3 ustawy o timeshare). Natomiast jeżeli miejsce zakwaterowania bądź inne obiekty udostępnione konsumentowi na podstawie umowy timeshare cechują się takimi wadami, że stanowią one zagrożenie dla zdrowia konsumenta bądź innych osób mających prawo korzystać z nich (tzn. z miejsca zakwaterowania i innych obiektów), to wtedy konsument ma prawo dokonać wypowiedzenia wspomnianej umowy z natychmiastowym skutkiem i to nawet wtedy, gdy zawierając umowę, miał wiedzę o wadach (art. 41 ustawy o timeshare).

W kontekście przedstawionych wyżej regulacji dotyczących przyczyn wypowiedzenia umowy timeshare należy jeszcze zaznaczyć, że - jak wskazuje się w literaturze przedmiotu - ustawa o timeshare nie wskazuje na maksymalny okres, na który można zawrzeć umowę o timeshare, zostawiając tę sprawę uzgodnieniom między stronami (Sagan, 2014: 24). Nie ma zatem przeszkód, aby strony umowy timeshare nie oznaczały czasu jej obowiązywania. $Z$ kolei do tego rodzaju zobowiązań bezterminowych bezpośrednio nawiązuje szczególna regulacja wynikająca $\mathrm{z}$ art. $365^{1}$ ustawy Kodeks cywilny (przepis ten stanowi: „Zobowiązanie bezterminowe o charakterze ciągłym wygasa po wypowiedzeniu przez dłużnika lub wierzyciela $\mathrm{z}$ zachowaniem terminów umownych, ustawowych lub zwyczajowych, a w razie braku takich terminów niezwłocznie po wypowiedzeniu”). Stosując ten przepis, strona nie będzie musiała - składając oświadczenie o wypowiedzeniu - wskazywać przyczyn, które nią kierowały, z tym że w przypadku postępowania sądowego sąd może kontrolować, czy takie wypowiedzenie odpowiada zasadom współżycia społecznego bądź społeczno-gospodarczemu przeznaczeniu prawa (art. 5 ustawy Kodeks cywilny), przy czym wypowiedzenie zobowiązania powoduje jego wygaśnięcie ze skutkiem na przyszłość (Wiśniewski, 2013: 113). 
Warunki odstąpienia od umowy przez konsumenta

Od wypowiedzenia umowy należy odróżnić procedurę odstąpienia od niej uregulowaną w rozdziale 5 ustawy o timeshare zatytułowanym Odstapienie od umowy przez konsumenta (art. 25-33 tej ustawy). Koncentrując się w dalszych rozważaniach na zasadach ogólnych, których zrozumienie ma kluczowe znaczenie dla właściwego stosowania przepisów analizowanej ustawy, należy w pierwszej kolejności zwrócić uwagę na regułę - determinującą w istotny sposób pozycję przedsiębiorcy wobec konsumenta - zawartą w art. 25 ust. 1 ustawy o timeshare, zgodnie z którą konsumentowi przysługuje „prawo odstąpienia od umowy timeshare, umowy o długoterminowy produkt wakacyjny, umowy pośrednictwa w odsprzedaży oraz umowy o uczestnictwo w systemie wymiany, bez podania przyczyny, w terminie 14 dni od dnia jej zawarcia lub od dnia doręczenia dokumentu umowy, jeżeli dzień ten następuje po dniu jej zawarcia”. Pewne modyfikacje dotyczące tego terminu określa art. 25 ust. 2 i 3 oraz art. 26 ustawy o timeshare. Natomiast pod względem wymogów formalnoprawnych dotyczących odstąpienia ustawodawca nie jest w tym zakresie zbyt restrykcyjny, stanowiąc w art. 28 ust. 1 ustawy o timeshare, że aby odstąpić od umowy należy tylko złożyć przedsiębiorcy - w formie pisemnej bądź przy wykorzystaniu innego trwałego nośnika informacji - oświadczenie w sprawie odstąpienia od umowy. Należy w tym miejscu wyjaśnić, że zgodnie z definicją zawartą w art. 6 pkt 5 ustawy o timeshare, pod pojęciem trwałego nośnika informacji kryje się „materiał lub urządzenie służące do przechowywania i odczytywania informacji przekazywanych konsumentowi w związku z umową timeshare, umową o długoterminowy produkt wakacyjny, umową pośrednictwa w odsprzedaży timeshare lub długoterminowego produktu wakacyjnego, lub umową o uczestnictwo w systemie wymiany, przez czas odpowiedni do celów, jakim informacje te służą oraz pozwalające na odtworzenie tych informacji w niezmienionej postaci”. Trzeba jeszcze dodać, że zgodnie z art. 28 ust. 3 ustawy o timeshare, by zachować termin odstąpienia od umowy wystarczy wysłać oświadczenie w sprawie odstąpienia przed upływem wspomnianego terminu na odstąpienie.

W kontekście powyższych rozwiązań prawnych kolejne pytanie, które się nasuwa, dotyczy konsekwencji odstąpienia od umowy, zarówno dla przedsiębiorcy, jak i dla konsumenta. Otóż konsekwencją realizacji przez konsumenta jego prawa do odstąpienia od umowy jest to, że uważa się ją za niezawartą (art. 29 ust. 1 ustawy o timeshare). Ponadto, konsument wolny jest od ponoszenia jakichkolwiek kosztów wiążących się z realizacją jego prawa do odstąpienia od umowy, a zwłaszcza nie spoczywa na nim obowiązek uiszczenia wynagrodzenia za te usługi, które przedsiębiorca wykonał przed dokonaniem odstąpienia od umowy, jak również nie musi zwracać korzyści, które mogłyby zostać uzyskane przez przedsiębiorcę, gdyby konsument nie zdecydował się odstąpić od umowy (art. 29 ust. 2 ustawy o timeshare).

\section{Szczególne powinności i ograniczenia spoczywające na przedsiębiorcach}

Niezależnie od omówionych wyżej rozwiązań prawnych, wyznaczających w sposób ogólny status przedsiębiorcy, ustawa o timeshare reguluje również szereg szczególnych obowiązków i zakazów spoczywających na przedsiębiorcach, które niejako dopełniają normatywny obraz pozycji prawnej przedsiębiorcy na gruncie rzeczonej ustawy. 
Na pierwszy plan wysuwa się spoczywający na przedsiębiorcy obowiązek informacyjny, który ma wiele przejawów szczegółowo uregulowanych w rozdziale 2 ustawy o timeshare zatytułowanym Obowiązki informacyjne przedsiębiorcy. Mianowicie przed podpisaniem umowy timeshare (tak samo ma się rzecz, gdy chodzi o umowę o długoterminowy produkt wakacyjny, umowę pośrednictwa w odsprzedaży i umowę o uczestnictwo w systemie wymiany) przedsiębiorca jest zobligowany do przekazania konsumentowi szczegółowych informacji dotyczących danej umowy, w granicach wyznaczonych standardowymi formularzami informacyjnymi, załączonymi w formie wzorów do ustawy o timeshare (art. 9 ustawy o timeshare). Rzeczone informacje muszą być przez przedsiębiorcę włączone do oferty zawarcia umów: timeshare, o długoterminowy produkt wakacyjny, pośrednictwa w odsprzedaży, uczestnictwo w systemie wymiany (art. 10 ust. 3 ustawy o timeshare). Jest też wymóg polegający na tym, że wszystkie te informacje muszą być przekazane przez przedsiębiorcę bezpłatnie, jasno i zrozumiale, pisemnie bądź z wykorzystaniem innego trwałego nośnika informacji (art. 10 ust. 4 ustawy o timeshare). Gdy chodzi o język informacji wymienionych w rzeczonym art. 9 ustawy o timeshare, to muszą być one przygotowane - stosownie do wyboru konsumenta - w języku mającym status języka urzędowego państwa należącego do Unii Europejskiej (istnieje zakaz sporządzania informacji w języku, który nie pełni roli języka urzędowego Unii Europejskiej), w którym konsument zamieszkuje bądź ma jego obywatelstwo, przy czym w sytuacji, gdy państwo to ma co najmniej dwa języki urzędowe, wystarczy sporządzić te informacje w jednym $\mathrm{z}$ tych języków, ale jego wybór należy do konsumenta (art. 10 ust. 5 ustawy o timeshare). Co więcej, przedsiębiorca nie może dokonywać jakichkolwiek zmian informacji wskazanych we wspomnianym art. 9 ustawy o timeshare bez zgody konsumenta (niedopuszczalne jest, by dorozumiewać zgodę konsumenta na takie zmiany), przy czym nie jest ona wymagana, gdy następuje działanie siły wyższej (art. 11 ust. 1 ustawy o timeshare). W sytuacji, gdy przedsiębiorca zaniechał - przed podpisaniem umowy - przekazania konsumentowi wszystkich informacji, które są wymagane w myśl art. 9 ustawy o timeshare, obowiązek przekazania tych informacji konsumentowi aktualizuje się po zawarciu umowy (art. 13 ustawy o timeshare).

Zgodnie z art. 15 ust. 1 ustawy o timeshare, reklamując timeshare, długoterminowy produkt wakacyjny, pośrednictwo w odsprzedaży timeshare lub długoterminowego produktu wakacyjnego, uczestnictwo w systemie wymiany - przedsiębiorca musi zawrzeć wiadomość na temat miejsca i sposobu uzyskania informacji wskazanych w powołanym wyżej art. 9 ustawy o timeshare. Ponadto, jak stanowi art. 15 ust. 2 ustawy o timeshare, przedsiębiorca przekazujący konsumentowi - w trakcie spotkań, zwłaszcza organizowanych w miejscu innym niż lokal przedsiębiorstwa - informacje handlowe związane z timeshare, długoterminowym produktem wakacyjnym, pośrednictwem w odsprzedaży timeshare lub długoterminowego produktu wakacyjnego, uczestnictwem w systemie wymiany, bądź też składający, w trakcie spotkań, konsumentom oferty, których przedmiotem jest zawarcie wspomnianych wyżej umów - musi w treści zaproszeń na spotkania wyraźnie oznaczyć, że mają one handlowy cel oraz charakter, przy czym na przedsiębiorcy spoczywa obowiązek zapewnienia dostępu do informacji koniecznych według art. 9 ustawy o timeshare przez cały okres trwania tego rodzaju spotkań. Co więcej, jak stanowi art. 15 ust. 3 ustawy o timeshare, przedsiębiorca ma zakaz przedstawiania jako inwestycji zawierania umów zarówno timeshare, jak i o długoterminowy produkt wakacyjny. 
Oprócz wspomnianego wyżej zakazu należy też pamiętać, że nie wolno - po pierwsze - żądać lub przyjmować od konsumenta żadnych świadczeń przewidzianych umową timeshare, o długoterminowy produkt wakacyjny lub o uczestnictwo w systemie wymiany, dopóki nie upłynie termin przewidziany na odstąpienie od umowy, a po drugie - żądać lub przyjmować od konsumenta żadnych świadczeń przewidzianych umową pośrednictwa w odsprzedaży, póki nie nastąpi nabycie lub zbycie przez konsumenta uprawnień z umowy timeshare lub o długoterminowy produkt wakacyjny bądź też rozwiązanie umowy (art. 34 pkt 1 i 2 lit. a i b ustawy o timeshare). Kolejny zakaz polega na tym, że $\mathrm{w}$ razie zawarcia pomiędzy konsumentem a przedsiębiorcą umowy przedwstępnej zobowiązującej do podpisania umowy timeshare, o długoterminowy produkt wakacyjny, pośrednictwa w odsprzedaży lub o uczestnictwo w systemie wymiany, nie można żądać lub przyjmować od konsumenta żadnych świadczeń ustalonych umową przedwstępną póki nie upłynie termin na odstąpienie od wspomnianej umowy przedwstępnej (art. 35 ustawy o timeshare). Żądaniem lub przyjmowaniem świadczeń, o których mowa w powołanych wyżej art. 34 i 35 ustawy o timashare, jest zwłaszcza sytuacja, kiedy od konsumenta żądane lub przyjmowane są: zaliczki, gwarancja bankowa lub ubezpieczeniowa, blokada rachunku bankowego bądź pisemne oświadczenie o uznaniu długu (art. 36 pkt 1-4 ustawy o timeshare).

\section{Ocena szczegółowych rozwiązań prawnych dotyczących relacji pomiędzy przedsiębiorcą a konsumentem}

Odniesienie się do nakreślonego na wstępie problemu badawczego dotyczącego pozycji prawnej przedsiębiorcy $\mathrm{w}$ relacjach $\mathrm{z}$ konsumentem wymaga dokonania oceny przedstawionych wyżej szczegółowych rozwiązań prawnych. W pierwszej kolejności wymaga rozważenia kwestia, czy wprowadzone przez ustawodawcę instrumenty - nakierowane na ochronę konsumenta - w postaci obowiązków informacyjnych spoczywających na przedsiębiorcy oraz prawa odstąpienia od umowy przez konsumenta są adekwatne dla realizacji wspomnianego celu ochronnego. Na tak postawione pytanie należy udzielić odpowiedzi zasadniczo twierdzącej, choć z pewną dozą krytyki. Wynika to z kilku przyczyn. Przede wszystkim ustawodawca nie ograniczył się do wprowadzenia jedynie ogólnie brzmiącego wymogu udzielenia informacji, ale szczegółowo określił, w jaki sposób należy ten obowiązek zrealizować. W szczególności zastrzegł, że musi on być zrealizowany poprzez standardowe formularze informacyjne, stanowiące załącznik do ustawy o timeshare (zob. art. 9 ustawy o timeshare), co wyklucza w tym zakresie dowolność ze strony przedsiębiorcy, który - gdyby takie formularze nie obowiązywały - mógłby ograniczyć się do informacji zbyt ogólnikowych i lakonicznych, co nie chroniłoby konsumenta w wystarczającym stopniu. Ustawodawca na tym jednak nie poprzestaje, bowiem nakazuje dodatkowo, aby rzeczone informacje były przekazane nieodpłatnie oraz jasno i zrozumiale (zob. art. 10 ust. 4 ustawy i timeshare), co wobec dość skomplikowanego języka prawnego dodatkowo chroni konsumentów, którzy przecież najczęściej nie mają wiedzy i doświadczenia pozwalających na jego właściwą wykładnię. Warto zwrócić uwagę na jeszcze jeden aspekt, mianowicie ten, że przekazane informacje są dla przedsiębiorcy wiążące (co w konsekwencji daje konsumentowi poczucie stabilności jego sytuacji prawnej), bowiem nie może on ich później w sposób dowolny zmieniać. Aby taka zmiana była możliwa, musi na nią wyrazić zgodę konsument bądź musi być ona spowodowana działaniem siły 
wyższej (zob. art. 11 ust. 1 ustawy o timeshare). Nieco krytycznie należy odnieść się do faktu, iż ustawodawca posłużył się ogólnym pojęciem siły wyższej, bez jakiejkolwiek egzemplifikacji takich przypadków. Z pewnością przysłużyłoby się to wzmocnieniu pewności obrotu prawnego i ułatwiłoby rozstrzyganie ewentualnych sporów sądowych pomiędzy przedsiębiorcą a konsumentem.

Jeżeli chodzi o przysługujące konsumentowi prawo do odstąpienia od umowy, to zostało ono unormowane w analizowanej ustawie w sposób szczegółowy, zgodny z poglądami doktryny na istotę tej instytucji prawnej oraz uwzględniający interesy konsumenta. Otóż należy przypomnieć, że odstąpieniem od umowy jest jednostronne oświadczenie woli kształtujące prawo, a stosunek prawny wygasa najczęściej ex tunc, czyli od chwili zawarcia umowy (Radwański, Olejniczak, 2014: 346). Zgodny z tą koncepcją jest przepis, w myśl którego w przypadku realizacji przez konsumenta jego prawa do odstąpienia od umowy, umowę uważa się za niezawartą (art. 29 ust. 1 ustawy o timeshare). Natomiast jako rozwiązanie szczególnie chroniące interesy konsumenta należy potraktować ustawowy zapis, zgodnie z którym odstąpienie przez konsumenta od umowy nie może wiązać się z koniecznością ponoszenia przez niego jakichkolwiek kosztów (zob. art. 29 ust. 2 ustawy o timeshare).

Kolejne pytanie, na które trzeba sobie odpowiedzieć, rozważając problem sytuacji normatywnej przedsiębiorcy w relacjach z konsumentem, dotyczy odpowiedniego wyważenia przez polskiego prawodawcę interesów przedsiębiorcy i konsumenta na gruncie ustawy o timeshare. Zagadnienie to pozostaje w ścisłym związku z problemem ryzyka kontraktowego występującego u przedsiębiorcy. Na temat rozwiązań chroniących interesy konsumenta była już mowa wyżej. Dlatego w tym miejscu poddane zostaną ocenie te unormowania, które mają na celu ochronę interesów przedsiębiorcy, a w konsekwencji ograniczenie jego ryzyka kontraktowego. Już pobieżna lektura ustawy o timeshare wskazuje, że unormowania te są bardzo nieliczne. Należy zwrócić uwagę na trzy takie przepisy. Po pierwsze, prawo konsumenta do odstąpienia od umowy może być zrealizowane tylko w ściśle określonym terminie dwutygodniowym (zob. art. 25 ust. 1 ustawy o timeshare), co ogranicza w czasie niepewność przedsiębiorcy co do przyszłości umowy. Po drugie, ustawodawca wymaga, aby przedsiębiorca otrzymał informację o odstąpieniu od umowy w formie pisemnej bądź z wykorzystaniem innego trwałego nośnika informacji (art. 28 ust. 1 ustawy o timeshare). Wymóg ten sprzyja pewności zarówno obrotu prawnego, jak i sytuacji prawnej przedsiębiorcy, a w szczególności zapobiega podejmowaniu przez konsumentów nieprzemyślanych decyzji o odstąpieniu od umowy. Po trzecie wreszcie, wiedza konsumenta w momencie zawarcia umowy o wadach udostępnionych mu - na podstawie umowy timeshare - obiektów wyklucza możliwość żądania obniżenia wynagrodzenia bądź wypowiedzenia umowy o natychmiastowym skutku (art. 40 ust. 3 ustawy o timeshare), choć są od tego wyjątki (zob. art. 41 ustawy o timeshare).

Na podstawie przywołanych regulacji można stwierdzić, że pomimo wyraźnych dysproporcji w zakresie ilości przepisów chroniących interesy konsumenta i przedsiębiorcy, ustawodawca odpowiednio wyważył interesy dwóch stron kontraktu (przedsiębiorcy i konsumenta). Nie sposób bowiem tej równowagi utożsamiać $\mathrm{z}$ pełną symetrią tych praw. Wynika to $\mathrm{z}$ faktu, że konsument jest stroną co do zasady mniej fachową od profesjonalnego przedsiębiorcy i ochrona tego pierwszego musi być większa, co oczywiście nie oznacza, że interesy przedsiębiorcy mają być przez prawodawcę całkowicie pomijane. W ustawie o timeshare interesy tego ostatniego nie zostały pominięte, chroniąc zwłaszcza pewność jego 
sytuacji prawnej. Tym samym ryzyko kontraktowe ponoszone przez przedsiębiorcę zostało ograniczone, choć nie wyeliminowane. Całkowite usunięcie takiego ryzyka w systemie gospodarki rynkowej opartej na zasadzie swobody kontraktowania nie jest zresztą możliwe. Ponadto trzeba mieć na uwadze, że zbyt daleko idące próby ustawowego zredukowania ryzyka kontraktowego musiałyby skutkować zawężeniem praw konsumenta, co z kolei stałoby w sprzeczności z obecnie istniejącym kierunkiem rozwoju prawa konsumenckiego. Tym samym dochodzimy tutaj do kwestii, czy występujący obecnie kierunek w jakim zmierza prawo konsumenckie, został należycie uwzględniony w ustawie o timeshare.

Niewątpliwie kierunek ten w rozpatrywanym obszarze normatywnym wyznaczony został przez Dyrektywę Parlamentu Europejskiego i Rady 2008/122/WE z dnia 14 stycznia 2009 r. $w$ sprawie ochrony konsumentów w odniesieniu do niektórych aspektów umów timeshare, umów o długoterminowe produkty wakacyjne, umów odsprzedaży oraz wymiany (Dziennik Urzędowy Unii Europejskiej L 33 z 3.02.2009, s. 10). Artykuł 1 ust. 1 rzeczonej dyrektywy wskazuje, że jej zadaniem jest „przyczynienie się do właściwego funkcjonowania rynku wewnętrznego i osiągnięcie wysokiego poziomu ochrony konsumentów przez zbliżenie przepisów ustawowych, wykonawczych i administracyjnych państw członkowskich w odniesieniu do niektórych aspektów marketingu, sprzedaży i odsprzedaży praw $\mathrm{z}$ umów timeshare oraz umów o długoterminowe produkty wakacyjne, a także umów wymiany". Ustawa o timeshare wdraża, jak wynika ze wzmianki zawartej w opublikowanym w Dzienniku Ustaw tekście tej ustawy, wspomnianą dyrektywę. Z uwagi na ograniczone ramy niniejszego opracowania nie jest możliwe poddanie szczegółowej analizie wszystkich rozwiązań zawartych w tejże dyrektywie. Można natomiast pokusić się o ogólną ocenę, czy trend w zakresie ochrony konsumentów wynikający z tej dyrektywy został rzeczywiście uwzględniony w ustawie o timeshare. Porównanie brzmienia dyrektywy z brzmieniem ustawy o timeshare pozwala stwierdzić, że trend ten został uwzględniony w ustawie o timeshare, pomimo występujących niekiedy różnic w brzmieniu przepisów dyrektywy i odpowiadających im regulacji ustawy o timeshare, co widać na przykładzie rozwiązań dotyczących terminu przysługującego konsumentowi na odstąpienie od umowy (por. art. 6 ust. 1 i 2 lit. a i b rzeczonej dyrektywy oraz art. 25 ust. 1 ustawy o timeshare).

\section{Refleksje podsumowujące}

Przeprowadzone w niniejszym opracowaniu omówienie głównych obowiązków przedsiębiorcy, wyznaczających jego pozycję prawną na gruncie ustawy o timeshare, skłania do pewnych refleksji. W pierwszym rzędzie nasuwa się konstatacja, iż ustawodawca stara się bardzo precyzyjnie określić relacje prawne łączące przedsiębiorcę z konsumentem, a tym samym i jego pozycję prawną. Jest to bardzo istotne dla utrzymania wiarygodności obrotu prawnego. Ma to także niewątpliwie walor edukacyjny nie tylko dla przedsiębiorców, ale również - a może nawet przede wszystkim - dla konsumentów. Poniekąd także przedsiębiorcy, jak wynika $\mathrm{z}$ analizowanej ustawy, zostali zobligowani do swego rodzaju „edukowania” konsumentów, na co wskazuje choćby wyszczególniony w art. 9 ustawy o timeshare nakaz szczegółowego informowania konsumentów o umowach regulowanych tą ustawą.

Kolejna refleksja, jaka nasuwa się po analizie rozwiązań prawnych zawartych w ustawie o timeshare, dotyczy możliwości zerwania więzi obligacyjnej pomiędzy przedsiębiorcą a konsumentem. Otóż ustawodawca dość szczegółowo uregulował - najpewniej 
także kierując się m.in. względami instrukcyjnymi - kwestię odstąpienia od umowy (cały rozdział 5 ustawy poświęcił tej problematyce) i wypowiedzenia umowy. Rozwiązanie to należy ocenić jako bardzo dobre, ponieważ pomaga budować zaufanie wśród podmiotów funkcjonujących w obrocie gospodarczym. Jest to szczególnie ważne, bowiem niestety w potocznym rozumieniu te dwie instytucje prawne są błędnie uważane za tożsame, co z kolei może prowadzić do nieprzewidzianych skutków. W tym kontekście należy przypomnieć, że m.in. od umowy timeshare konsument może odstąpić bez podawania żadnej przyczyny, ale w ściśle określonym terminie (zob. art. 25 ust. 1 ustawy o timeshare). Odmiennie wygląda sytuacja w przypadku wypowiedzenia umowy, które to wypowiedzenie uwarunkowane jest co do zasady określonymi przesłankami (zob. art. 40 ust. 2 i 3 oraz art. 41 ustawy o timeshare), przy czym - jak już zostało to wyżej omówione - gdy w umowie nie oznaczono czasu jej obowiązywania, to wówczas strona może powołać się na przepis art. $365^{1}$ ustawy Kodeks cywilny, którego zastosowanie - jak wskazuje się w doktrynie pozwala na niewskazywanie w treści wypowiedzenia jego przyczyn (Wiśniewski, 2013: 113).

Akty prawne i literatura

Legal acts and references

Dyrektywa Parlamentu Europejskiego i Rady 2008/122/WE z dnia 14 stycznia 2009 r. w sprawie ochrony konsumentów w odniesieniu do niektórych aspektów umów timeshare, umów o dlugoterminowe produkty wakacyjne, umów odsprzedaży oraz wymiany (Dziennik Urzędowy Unii Europejskiej L 33 z 3.02.2009, 2019, 7 sierpnia). Pozyskano z: https://eur-lex.europa.eu/legal-content/PL/TXT/ $\mathrm{PDF} /$ ?uri $=$ CELEX:32008L0122\&from $=\mathrm{PL}$

Ustawa z dnia 23 kwietnia 1964 r. Kodeks cywilny (tekst jednolity: Dz.U. z 2019 r., poz. 1145).

Ustawa z dnia 16 września 2011 r. o timeshare (Dz.U. z 2011 r. nr 230, poz. 1370).

Dmowski, S., aktualizacja Trzaskowski, R. (2014). W: S. Dmowski, S. Rudnicki, R. Trzaskowski. Kodeks cywilny. Komentarz. Część ogólna. Tom I, pod red. J. Gudowskiego. Warszawa: Wydawnictwo LexisNexis.

Fuchs, B. (2012). Regulacja timesharingu a Kodeks cywilny. W: M. Jagielska, E. Rott-Pietrzyk, A. Wiewiórowska-Domagalska (red.), Kierunki rozwoju europejskiego prawa prywatnego. Wplyw europejskiego prawa konsumenckiego na prawo krajowe. Warszawa: Wydawnictwo C.H. Beck, 153-167.

Fuchs, B. (1997). Timesharing. Rejent, 4, 33-51.

Fuchs, B. (2001). Timesharing w obrocie międzynarodowym (aspekty kolizyjnoprawne). Rejent, 7-8, 49-59.

Gołaczyńki, J. (2001). Timesharing - zagadnienia kolizyjnoprawne. Rejent, 7-8, 60-81.

Grzyb, K. (2004). Umowa timesharingu w prawie polskim. Rejent, 9, 30-47.

Kruczalak, K., zaktualizowała i uzupełniła Kruczalak-Jankowska, J. (2008). Prawo handlowe. Zarys wykładu. Warszawa: Wydawnictwo Prawnicze LexisNexis.

Preussner-Zamorska, J., Traple, E. (1998). Timesharing - nowa instytucja prawa polskiego. Uwagi na marginesie projektu ustawy. Kwartalnik Prawa Prywatnego, 3, 537-547.

Radwański, Z., Olejniczak, A. (2014). Zobowiq̨zania - cześśc ogólna. Warszawa: Wydawnictwo C.H. Beck. Sagan, B. (2014). Ustawa o timeshare. Komentarz. Warszawa: Wydawnictwo LexisNexis.

Stecki, L. (2002). Timesharing. Toruń: Wydawnictwo „Dom Organizatora”.

Wiśniewski, T. (2013). W: T. Bielska-Sobkowicz, G. Bieniek, H. Ciepła, P. Drapała, J. Gudowski, M. Sychowicz, R. Trzaskowski, T. Wiśniewski, Cz. Żuławska, Kodeks cywilny. Komentarz. Zobowiazania. Tom III, cz. 1, pod red. J. Gudowskiego. Warszawa: Wydawnictwo LexisNexis.

Zaradkiewicz, K. (1997). Umowa timesharingu a regulacje Unii Europejskiej. Monitor Prawniczy, 5, 185-193. 
Paweł Marek Woroniecki, dr nauk prawnych, Uniwersytet Jagielloński w Krakowie, Wydział Prawa i Administracji, Katedra Polityki Gospodarczej. Autor w ramach swojej aktywności naukowej analizuje rozwiązania prawne z zakresu finansów publicznych (państwowych i samorządowych), regulacje związane $\mathrm{z}$ funkcjonowaniem przedsiębiorców w systemie gospodarczym, a zwłaszcza ich sytuację prawną oraz normatywne podstawy działalności administracji publicznej.

Paweł Marek Woroniecki, doctor of legal sciences, the Jagiellonian University, Faculty of Law and Administration, Chair of Economic Policy. Author within his research activity analyses legal solutions in the field of public finances (governmental and local government), regulations connected with functioning of entrepreneurs in economic system, particularly their legal situation, and normative grounds of public administration's activity.

ORCID: 0000-0002-0352-1042

\section{Adres/Address:}

Uniwersytet Jagielloński w Krakowie

Wydział Prawa i Administracji

Katedra Polityki Gospodarczej

ul. Bracka 12

31-005 Kraków, Polska

e-mail: pawel.woroniecki@uj.edu.pl 